\title{
Which Past Returns Affect Trading Volume?
}

\author{
Markus Glaser and Martin Weber*
}

July 12, 2007

\begin{abstract}
Anecdotal evidence suggests and recent theoretical models argue that past stock returns affect subsequent stock trading volume. We study 3,000 individual investors over a 51 month period to test this prediction using several different panel regression models (linear panel regressions, negative binomial panel regressions, Tobit panel regressions). We find that both past market returns as well as past portfolio returns affect trading activity of individual investors (as measured by stock portfolio turnover, the number of stock transactions, and the propensity to trade stocks in a given month). After high portfolio returns, investors buy high risk stocks and reduce the number of stocks in their portfolio. High past market returns do not lead to higher risk taking or underdiversification. We argue that the only explanations for our findings are overconfidence theories based on biased self-attribution and differences of opinion explanations for high levels of trading activity.
\end{abstract}

Keywords: Individual Investors, Investor Behavior, Trading Volume, Stock Returns and Trading Volume, Overconfidence, Differences of Opinion, Discount Broker, Online Broker, Online Banks, Panel Data, Count Data

JEL Classification Code: D8, G1

* Markus Glaser is from the Lehrstuhl für Bankbetriebslehre, Universität Mannheim, L 5, 2, 68131 Mannheim. E-Mail: glaser@bank.BWL.uni-mannheim.de. Martin Weber is from the Lehrstuhl für Bankbetriebslehre, Universität Mannheim, L 5, 2, 68131 Mannheim and CEPR, London. E-Mail: weber@bank.BWL.uni-mannheim.de. We would like to thank Julie Agnew, Markus Brunnermeier, Frank Ecker, Simon Gervais, John Griffin, Pete Kyle, Andreas Oehler, Zacharias Sautner, Peter Schotman, Daniel Schunk, Marno Verbeek, Rudy De Winne, and seminar participants at the University of Mannheim, the Stockholm Institute for Financial Research (SIFR) conference on Portfolio Choice and Investor Behavior, the Finance Brown Bag seminar, Fuqua School of Business, Duke University, the Conference of the Swiss Society for Financial Market Research, Zürich, the Tagung des Verbandes der Hochschullehrer für Betriebswirtschaft (Pfingsttagung), Kiel, and the Arne Ryde Workshop in Financial Economics, Lund, for valuable comments and insights. Parts of this paper were written while Markus Glaser was visiting the Fuqua School of Business, Duke University, North Carolina, USA, and the Swedish Institute for Financial Research (SIFR), Stockholm, Sweden. Financial Support from the Deutsche Forschungsgemeinschaft (DFG) is gratefully acknowledged. 


\title{
Which Past Returns Affect Trading Volume?
}

\begin{abstract}
Anecdotal evidence suggests and recent theoretical models argue that past stock returns affect subsequent stock trading volume. We study 3,000 individual investors over a 51 month period to test this prediction using several different panel regression models (linear panel regressions, negative binomial panel regressions, Tobit panel regressions). We find that both past market returns as well as past portfolio returns affect trading activity of individual investors (as measured by stock portfolio turnover, the number of stock transactions, and the propensity to trade stocks in a given month). After high portfolio returns, investors buy high risk stocks and reduce the number of stocks in their portfolio. High past market returns do not lead to higher risk taking or underdiversification. We argue that the only explanations for our findings are overconfidence theories based on biased self-attribution and differences of opinion explanations for high levels of trading activity.
\end{abstract}

Keywords: Individual Investors, Investor Behavior, Trading Volume, Stock Returns and Trading Volume, Overconfidence, Differences of Opinion, Discount Broker, Online Broker, Online Banks, Panel Data, Count Data

JEL Classification Code: D8, G1 


\section{Introduction}

Practitioners claim and anecdotal evidence suggests that past stock returns affect stock market trading volume. For example, a report from Deutsche Bank Research on the crisis of the German online brokerage market argues that "the declines in the equity markets have severely curbed the trading activities of these investors, eroding the online brokers' chief source of income." ${ }^{1}$ Similarly, Deloitte \& Touche's 2001 survey of online securities trading writes that "the decline in stock prices between Spring 2000 and Spring 2001 has led to slower growth of new online accounts and reduced trading volumes." ${ }^{2}$

The conjecture that past returns affect trading volume might be true, as Figure 1 suggests. The figure show the time series of the German market index DAX from January 1997 to March 2001 (end of month values) and the time series of the sum of stock transactions per month of a sample of individual investors from a German online broker. ${ }^{3}$

Why should past stock returns affect trading volume? Recently, theories have been proposed that are able to explain this link: High returns make investors overconfident and, as a consequence, these investors trade more subsequently. ${ }^{4}$ However, these models are silent about the question which past returns affect trading volume: past stock market returns, past portfolio returns of individual investors, or both? Usually, only one risky asset is traded in theoretical models such that, in these models, past portfolio returns are equal to past market returns. ${ }^{5}$ Figure 1 might be interpreted as evidence that past market returns affect the number of stock transactions of individual investors. Barber and Odean (2002) analyze a data set from a U.S. discount broker. They argue and find that high past portfolio returns induce individual investors to switch from phone-based to online trading. As a consequence, investors trade more subsequently. Statman, Thorley, and Vorkink (2006) find that market wide trading volume in the U.S. is related to past market returns. Griffin, Nardari, and Stulz (2007) analyze the dynamic relation between

\footnotetext{
${ }^{1}$ Deutsche Bank Research, E-conomics, No. 26, April 19, 2002, www.dbresearch.com.

${ }^{2}$ Deloitte \& Touche, Online Securities Trading 2001, www.deloitte.com.

${ }^{3}$ See Section 3 for details about the investor sample.

${ }^{4}$ See Section 2 for a discussion of overconfidence models.

${ }^{5}$ See Section 2 for details.
} 
market-wide trading activity and returns in 46 countries and show that many stock markets exhibit a strong positive relation between turnover and past returns. To summarize so far, empirical evidence suggests that both market returns and portfolio returns affect trading volume. ${ }^{6}$

One interpretation of these results is that past market returns and past portfolio returns drive different facets of overconfidence. High past market returns could make investors overconfident in the way that they underestimate the volatility of stock returns. Deaves, Lüders, and Schröder (2007) present evidence in favor of this interpretation. They examine both the statics and dynamics of overconfidence of stock market forecasters using a monthly survey of financial market practitioners. Respondents are asked for confidence intervals for the level of the German market index DAX six months ahead. Thus, the authors obtain a panel of overconfidence measures that can be calculated by the width of the confidence intervals stated. They analyze (among other things) the relation between past DAX returns and overconfidence and find that high past market returns influence stated confidence intervals in the direction of increasing overconfidence.

In contrast, success in the past, i.e. high past portfolio returns might make investors overconfident in the way that overestimate their investment skills. Due to a self-attribution bias they think that they are better than other investors (see, for example, Hilary and Menzly (2006) and the references cited therein).

The main goal of our study is to analyze the question which past returns affect trading volume of individual investors more comprehensively. Do past own stock portfolio returns or market returns have a stronger impact on the trading activity and the subsequent risktaking of investors? Stated in other words, we disentangle the two forms of overconfidence mentioned above. To do this, we study a panel data set of individual investors who have discount broker accounts over a 51 month period using various cross-sectional time-series regression models.

Gaining knowledge about this issue is important to get a deeper understanding of how financial markets work and how trading activity of investors is determined. Our results can thus help to build more realistic models of financial markets. Furthermore, the results

\footnotetext{
${ }^{6}$ We present an in-depth discussion of these empirical studies in Section 3.
} 
are useful for online brokers. As was discussed above, profits of online brokers are closely linked to the trading volume of investors. Thus, knowing how their customers behave and what the determinants of their trading activity are is necessary to, for example, optimize the online brokers' customer portfolio, the transaction fee structures, and the allocation of marketing expenditures. ${ }^{7}$

Our main results can be summarized as follows. Both past market returns as well as past portfolio returns affect trading activity of individual investors (as measured by stock portfolio turnover, the number of stock transactions, and the propensity to trade stocks) and are thus able to confirm predictions of overconfidence models. However, other explanations predict a positive link between past returns and trading activity as well. In a next step, we thus evaluate these further explanations. Only high past portfolio returns lead to higher risk taking. After high portfolio returns, investors buy high risk stocks and reduce the number of stocks in their portfolio. High past market returns do not lead to higher risk taking or underdiversification. We argue that the only explanations of our findings are overconfidence theories based on biased self-attribution and differences of opinion explanations of high levels of trading activity.

The rest of the paper is organized as follows. The next section discusses related literature. Section 3 describes our data set and the methodology we employ. Section 4 shows the results on past returns and trading activity and presents several robustness checks. Section 5 discusses alternative explanations of the results and show the results on past returns and risk taking. The last section discusses our results and concludes.

\section{Related Literature}

Why should past stock returns affect trading volume? In this section, we discuss overconfidence models that are able to explain this link more comprehensively. ${ }^{8}$ These theories argue that high returns make investors overconfident and as a consequence these investors trade more subsequently. Daniel, Hirshleifer, and Subrahmanyam (1998) propose a model

\footnotetext{
${ }^{7}$ See, for example, Zeithaml, Rust, and Lemon (2001) and Reinartz, Thomas, and Kumar (2005).

${ }^{8}$ For an in-depth discussion of various overconfidence models, their main predictions as well as several empirical tests of these models see Glaser, Nöth, and Weber (2004).
} 
in which the degree of overconfidence, modeled as the degree of the underestimation of the variance of signals, is a function of past investment success. This modeling assumption is motivated by psychological studies that find biased self-attribution (see Wolosin, Sherman, and Till (1973), Langer and Roth (1975), Miller and Ross (1975), Schneider, Hastorf, and Ellsworth (1979)): People overestimate the degree to which they are responsible for their own success. Hirshleifer (2001) argues that "overconfidence and biased self-attribution are static and dynamic counterparts" . ${ }^{9}$ Benos (1998), Caballé and Sákovics (2003), Kyle and Wang (1997), Odean (1998b), and Wang (1998) incorporate this way of modeling overconfidence in different types of models such as those of Diamond and Verrecchia (1981), Hellwig (1980), Grossman and Stiglitz (1980), Kyle (1985), and Kyle (1989). These models predict that overconfidence leads to high trading volume. Odean (1998b) calls this finding "the most robust effect of overconfidence". As long as past returns are a proxy for overconfidence, these models postulate a positive lead-lag relationship between past returns and trading volume. The intuition behind this link is as follows. High total market returns make (some) investors overconfident about the precision of their information. Investors mistakenly attribute gains in wealth to their ability to pick stocks. As a result they underestimate the variance of stock returns and trade more frequently in subsequent periods because of inappropriately tight error bounds around return forecasts. Furthermore, Odean (1998b) shows that overconfident traders choose a riskier portfolio than they would hold without overconfidence.

Gervais and Odean (2001) analyze the link between past returns and trading volume more formally. They develop a multiperiod model in which traders learn about their ability. This learning process is affected by biased self-attribution. The investors in the model attribute past success to their own abilities which makes them overconfident. Accordingly, the degree of overconfidence dynamically changes over time. They predict that overconfidence is higher after market gains and lower after market losses. Gervais and Odean (2001) show that "greater overconfidence leads to higher trading volume" and that "this suggests that trading volume will be greater after market gains and lower after market losses". ${ }^{10}$ However, it is important to note that Gervais and Odean (2001) analyze an economy in which only one risky asset is traded. Thus, in their model, the market return is identical to

\footnotetext{
${ }^{9}$ Hirshleifer (2001), p. 1549.

${ }^{10}$ Gervais and Odean (2001), p. 2.
} 
the portfolio returns of investors. Accordingly, the Gervais and Odean (2001) model makes no predictions about which past returns (market returns or portfolio returns) affect trading volume. In other words, overconfidence models by definition use investor's portfolios. These portfolios could be the market portfolio if no other assets are specified, but in a like manner actual investor's portfolios could be the market if they only hold market funds. References in these papers to market returns can also be regarded as ad hoc estimates of portfolio values. ${ }^{11}$

Statman, Thorley, and Vorkink (2006) test the market trading volume prediction of formal overconfidence models using U.S. market level data. They find that monthly market turnover, their measure of trading volume, is positively related to lagged market returns. Vector autoregressions and associated impulse response functions indicate that individual security turnover is positively related to lagged market returns as well as to lagged returns of the respective security. Kim and Nofsinger (2007) confirm these findings using Japanese market level data. They identify stocks with varying degrees of individual ownership to test the hypothesis and discover higher monthly turnover in stocks held by individual investors during the bull market in Japan. Griffin, Nardari, and Stulz (2007) investigate the dynamic relation between market-wide trading activity and returns in 46 countries. Many stock markets exhibit a strong positive relation between turnover and past returns. These findings hold when they control for volatility, alternative definitions of turnover, differing sample periods, and are present at both the weekly and daily frequency. Barber and Odean (2002) test the prediction of overconfidence models using a data set from a U.S. discount broker. They analyze trading volume and performance of a group of 1,600 investors who switched from phone-based to online trading during the sample period. They find that those who switch to online trading perform well prior to going online and beat the market. Furthermore, they find that trading volume increases and performance decreases after going online. This finding is consistent with the prediction that high returns in the past make investors overconfident who, as a consequence, trade more subsequently. Barber and Odean (2002) thus conclude that "overconfident investors were more likely to go online and once online the illusion of control and the illusion of knowledge further

\footnotetext{
${ }^{11}$ There is, however, another interpretation. Although the price increases are market wide, investors mistakenly attribute gains in wealth to their ability to pick stocks. The implicit assumption behind this is that market returns and portfolio returns are correlated. This is true for our data set. The correlation is positive $(0.47)$ and highly significant ( $p$-value of $p<0.0001)$ but far from perfect. See Section 3 for details.
} 
increased their overconfidence. Overconfidence led them to trade actively...". ${ }^{12}$

Our study differs from the above mentioned papers in the following dimensions: We study a panel data set of individual investors using cross-sectional time-series regression models. Furthermore, we investigate whether market returns and portfolio returns have a different impact on measures of trading activity and we are able to analyze which past returns have a stronger effect on volume. Furthermore, we analyze whether investors engage in higher risk taking in response to high past returns which is impossible with aggregate data.

Furthermore, our study is part of the empirical literature that tests the prediction of overconfidence models that overconfidence leads to high trading volume by analyzing trading decisions of private investors. Odean (1999) analyzes trades of 10,000 individuals with U.S. discount brokerage accounts. He finds that these investors reduce their returns by trading and thus concludes that trading volume is excessive - a finding which is consistent with overconfidence models. Barber and Odean (2001) use gender as a proxy for overconfidence. In their paper, they summarize psychological studies that find a higher degree of overconfidence among men than among women. Thus, they partition their data set which consist of 35,000 households from a large discount brokerage house by means of gender and find that men trade more than women which is consistent with overconfidence models. Glaser and Weber (2007) measure various facets of overconfidence in a sample of online broker investors using a questionnaire. Thus, they are able to link measures of overconfidence and measures of trading volume for this group of individual investors. One finding of their study is that investors who think that they have above average investment skills (but who do not have above average returns) trade significantly more.

\section{Data Set and Methodology}

This study is based on the combination of several data sets. The main data set consists of 563,104 buy and sell transactions as well as monthly portfolio positions of 3,079 individual investors from a German online broker in the period from January 1997 to mid April 2001. We consider all investors who trade via internet, had opened their account

\footnotetext{
${ }^{12}$ Barber and Odean (2002), p. 479.
} 
prior to January 1997, and had at least one transaction in $1997 .{ }^{13}$ The second data set consists of demographic and other self-reported information (age, gender, income, investment strategy, investment experience), that was collected by the online broker at the time each investor opened her or his account. Data on the securities traded is obtained from Datastream, our third data source.

Table 1 presents descriptive statistics of the data set. The table shows descriptive statistics about age, the stock market investment experience (in years), the number of transactions in all security categories (sum over the period from January 1997 to mid April 2001), the number of stock transactions (sum over the period from January 1997 to mid April 2001), the number of warrant transactions (sum over the period from January 1997 to mid April 2001), the average of the monthly stock portfolio value (in EUR), the number of stocks in portfolio (time series average across investors), income (in EUR), the average of the monthly stock portfolio turnover from January 1997 to March 2001, the average of the monthly stock portfolio performance, the percentage of investors who describe their investment strategy as high-risk, the percentage of investors who use their account for retirement savings, and the percentage of female investors in our investor sample. The table contains means and medians of these variables as well as the number of observations of the respective variable. Income is reported within five ranges, where the top range is more than 102,258.38 EUR (200,000 Deutsche Mark (DEM)). We calculate means and medians using the midpoint of each range and 115,040.67 EUR (225,000 DEM) for the top range. Investment experience is reported within five ranges, where the top range is more than 15 years. We calculate means and medians using the midpoint of each range and 17.5 years for the top range. Stock portfolio turnover in a given month is calculated as follows. We calculate the sum of the absolute values of purchases and sales per month for each investor and divide this sum by the respective end-of-month stock portfolio position. We calculate the monthly gross portfolio performance of each investor making the following simplifying assumptions. We assume that all stocks are bought and sold at the end of the month, and we ignore intra-month trading. Barber and Odean (2000) and Barber and Odean (2002) show that these simplifying assumptions do not bias the measurement of

\footnotetext{
${ }^{13}$ See Glaser (2003) for descriptive statistics and further details. Not necessarily all orders are placed online but all investors traded via the internet at least once during our sample period. We consider all trades by these investors, i.e. we include the trades that were placed by telephone, for example.
} 
portfolio performance. The gross portfolio return $R_{h t}$ of investor $h$ in month $t$ is calculated as follows:

$$
R_{h t}=\sum_{i=1}^{S_{h t}} w_{i h t} R_{i t} \quad \text { with } \quad w_{i h t}=\frac{P_{i t} n_{i h t}}{\sum_{i=1}^{S_{h t}} P_{i t} n_{i h t}}
$$

$R_{i t}$ is the return of stock $i$ in month $t, S_{h t}$ is the number of stocks held by individual $h$ in month $t, P_{i t}$ is the price of stock $i$ at the beginning of month $t$, and $n_{i h t}$ is the number of stocks of company $i$ held by investor $h$ in month $t$. $w_{i h t}$ is the beginning-of-month- $t$ market value of the holding of stock $i$ of investor $h$ divided by the beginning-of-month- $t$ market value of the whole stock portfolio of investor $h$.

In Table 1, we exclude investors with less than 5 turnover observations to calculate the average of the monthly stock portfolio turnover and we exclude investors with stock positions in 12 or fewer months to calculate the average of monthly stock portfolio performance.

With the help of the year in which the account was opened, we are able to calculate the age and stock investment experience in our panel data set. ${ }^{14}$ For example, the age of an investor who has opened an account in 1996 with an age of 39 is 41 years old in our panel data set in $1998 .^{15}$

Our basic empirical model is specified as follows:

$$
\text { Trading } \text { Activity }_{h t}=f\left(R_{t-1}^{m} ; R_{h, t-1}^{p} ; \mathbf{x}_{h} ; \mathbf{y}_{h t} ; \mathbf{z}_{t}\right)
$$

with

- Trading Activity $_{h t}$ : trading activity (i.e. stock portfolio turnover, number of stock transactions, propensity to trade) of investor $h$ in month $t$.

- $R_{t-1}^{m}$ : stock market return in month $t-1$.

- $R_{h, t-1}^{p}$ : stock portfolio return of investor $h$ in month $t-1$.

\footnotetext{
${ }^{14} 981$ accounts were opened in 1994, 651 accounts were opened in 1995, and 1,447 accounts were opened in 1996.

${ }^{15}$ The exact date of birth is unavailable.
} 
- $\mathbf{x}_{h}$ : control variables that vary across investors, but are constant for investor $h$ over time (such as self-assessment of the riskiness of the own investment strategy).

- $\mathbf{y}_{h t}$ : control variables that vary across investors and over time (such as the stock portfolio value or age).

- $\mathbf{z}_{t}$ : control variables that do not vary across investors but vary over time (such as stock market volatility).

To analyze our data set we use linear panel regressions as well as negative binomial panel regressions and Tobit panel regressions (see Greene (2003), Wooldridge (2002), Baltagi (2001), and Winkelmann (2003) for details). Nicolosi, Peng, and Zhu (2007) use an approach similar to ours. They investigate, among other things, whether security analysis ability, estimated from past trading experience, affects individual investors' future stock purchases. They run fixed-effect panel regressions of turnover on several explanatory variables. They also include past portfolio performance and past market returns as control variables. Another related paper is the study of Grinblatt and Keloharju (2001). They analyze the determinants of the trading behavior of Finnish investors using Logit regressions. The dependent variable is a dummy variable that is set equal to one when an investor sells a stock and zero when an investor does not sell a stock. They also include past return variables over various horizons. Besides past market returns they include, in contrast to our study, past market-adjusted stock returns. Thus, they are unable to measure the impact of past portfolio returns on the decision to sell. Another study that disentangles the influence of various past returns on measures of trading activity is the paper by Choe, Kho, and Stulz (1999). They analyze the impact of past market returns and past individual stock returns on order imbalance of stocks traded by various investor groups in Korea (see Choe, Kho, and Stulz (1999), Table 7). They do not include past portfolio returns in their regressions. Agnew (2005) analyzes how individuals react to market returns in one 401(k) plan using negative binomial regressions. She also includes several lagged market returns.

To analyze whether investors with high past returns actually take more risk afterwards we need to analyze the riskiness of stocks bought in the following month. To do this, we gather data from Datastream on the more than 4,000 stocks traded by the investors in our data set. Table 3 presents mean, median, and percentiles of several characteristics 
(average daily stock returns, volatility, unadjusted price, monthly trading volume, market capitalization, market to book ratio, dividend yield). The stock preferences of our investor sample in general are twisted towards small, thinly traded high book-to-market stocks.

Table 4 presents correlation coefficients of our key variables. A first inspection of the data shows that they are consistent with the two hypotheses concerning trading activity and risk taking in response to high returns: Turnover is significantly positively correlated with both past market as well as past portfolio returns. Past market returns are never significantly positively correlated with our measures of the riskiness of stock purchases (the logarithm of the average market-to-book ratio of stocks purchased in a given month, the average standard deviation of daily returns of stocks purchased in a given month, the logarithm of the average market capitalization of stocks purchased in a given month). In contrast, past portfolio returns lead to purchases of stocks with higher book-to-market ratios as well as higher standard deviation of returns. Furthermore, high returns in the past are associated with a lower number of stocks in the portfolio afterwards. In the following sections, we further analyze these relations using various panel regression models.

\section{Past Returns and Trading Volume: Results}

\subsection{Basic Results}

Table 5 presents regression results on the relation between several measures of trading activity and past returns. Depending on the respective trading activity measure, we use the appropriate regression model. Regressions (1) to (4) are random and fixed effects ordinary least squares panel regressions. Dependent variables are the logarithm of monthly stock portfolio turnover (Regressions (1) and (2)) and $\ln (1+$ turnover) (Regressions (3) and (4)). Regression (5) shows results of a Tobit regression. Regressions (6) to (9) present random and fixed effects ordinary least squares panel regressions again. Dependent variables are the logarithm of the number of stock transactions (Regressions (6) and (7)) and $\ln (1+$ number of stock transactions) (Regressions (8) and (9)). In Regressions (10) and (11), we present negative binomial panel regressions. The last regression contains a pooled Logit regression. 
In our data set, 61,399 monthly turnover observations have the value 0 . Thus, these observations drop out when we only calculate the logarithm of turnover. A widely used measure to avoid this problem is to transform turnover as the logarithm of ( $1+$ turnover). These transformations are widely used in the literature. Dorn and Huberman (2007), for example, analyze $\ln (1+$ turnover $)$ as dependent variable. Grinblatt and Keloharju (2006) analyze the logarithm of the number of trades and turnover. Grinblatt and Keloharju (2001) analyze the propensity to trade.

Explanatory variables are the respective lagged trading volume measure to control for potential autocorrelation in trading activity, stock market investment experience, age of an investor, a warrant trader dummy, a high-risk investment strategy dummy, the logarithm of the monthly stock portfolio value, the stock market volatility (standard deviation of daily DAX returns in a given month) as well as past stock market and portfolio returns (one lag). Section 3 and Table 2 present definitions of the variables. These explanatory variables are known to affect financial decision making. ${ }^{16}$ We use the natural logarithm of the stock portfolio value and the trading volume measures as these variables are positively skewed. Tests show, that we thus avoid problems like non-normality, non-linearity, and heteroscedasticity in the regression analysis (see Spanos (1986), chapter 21, especially, pp. 455-456, Davidson and McKinnon (1993), chapter 14, and Atkinson (1985), pp. 80-81).

The main finding of this table is that both past market returns and past portfolio returns are significantly positively related to trading activity. This result does not depend on the regression specification and the measure of trading activity analyzed. Statman, Thorley, and Vorkink (2006), Griffin, Nardari, and Stulz (2007), and Chuang and Lee (2006) report similar results using market level data. They find that trading activity depends on past market wide returns. Dorn and Huberman (2007) analyze the link between turnover and volatility using a data set similar to ours. They write in their paper that turnover strongly depends on past returns but they do not present the regression coefficients. Nicolosi, Peng, and Zhu (2007) also analyze a data set from a discount broker to analyze whether investors learn from trading experience. They also find that both past market as well as past portfolio returns positively affect trading activity. They report coefficients and

\footnotetext{
${ }^{16}$ See, e.g., Barber and Odean (2001), Dorn and Huberman (2005), Glaser (2003), Grinblatt and Keloharju (2001), Griffin, Nardari, and Stulz (2007), or Vissing-Jorgensen (2003).
} 
t-statistics that are similar to ours. Interestingly, they also report that the effect of past market returns is slightly larger with a higher $t$-value.

Furthermore, trading activity strongly depends on the respective lagged trading activity measure. Thus, there is some form of persistence or autocorrelation of trading activity measures over time. ${ }^{17}$ We thus confirm results of other studies that present a strong dependence of trading activity on lagged trading activity (see, for example, Statman, Thorley, and Vorkink (2006) or Nicolosi, Peng, and Zhu (2007)). Even the magnitude and significance of our results are similar to other studies using the same regression models (see, for example, Dorn and Huberman (2007) who also analyze Tobit regressions and present results similar to our Regression (5)).

The high $t$-values are not surprising given the large number of observations. Grinblatt and Keloharju (2001) present an in-depth discussion of this point in their study that is related to ours. They argue that "isolated $t$-statistics of less than three $\ldots$ are unimpressive, even though such $t$-statistics represent statistical significance at the 1 percent level". ${ }^{18}$

We also find that stock market investment experience and age have a positive effect on turnover. Warrant traders trade significantly more stocks (as measured by higher turnover values). The warrant trader dummy are usually highly speculative traders. Bank-issued warrants are comparable to options but with some institutional differences. For example, warrants are always issued by financial institutions (see Schmitz, Glaser, and Weber (2005) for details). ${ }^{19}$ Investors who describe their investment strategy as high-risk have higher turnover values. The higher the stock portfolio value, the lower the stock portfolio turnover. Note, that all time-invariant variables are eliminated from the fixed effects model (regression (3)). This is also true for the age variable as the difference between age and investment experience is a constant for each investor in our data set (see Section 3). The low number of observations is due to the fact that only 2,998 investors in our data set trade stocks. Furthermore, the self-reported age and investment experience variables

\footnotetext{
${ }^{17}$ Tests show that for about half of our investors exhibit a significant positive autocorrelation in trading activity whereas the other investors do not.

${ }^{18}$ See Section 3 and Grinblatt and Keloharju (2001), p. 598.

${ }^{19}$ Schmitz, Glaser, and Weber (2005) also show that hedging is a very unlikely trading motive for warrant traders. For example, the holding period of warrants is usually only a couple of days.
} 
are only available for 2,552 and 2,386 investors, respectively (see Table 1 for details). The omission of these two variables and the inclusion of the income variable do not alter our results concerning past returns and trading volume. Our results hold for different sets of explanatory variables.

The results in Regressions (6) to (9) in which we analyze the number if transactions are similar to those presented before with a few exceptions. The stock portfolio value is positively related to the number of transactions. The result that the sign of portfolio size is either positive (with the number of transactions as dependent variable) or negative (with turnover as dependent variable) in the different regressions is intuitive. Given that there are fixed transaction costs per transaction it makes sense that investors with a higher portfolio value place more orders. In contrast, portfolio value and turnover are negatively correlated as turnover is trading volume relative to portfolio size. Furthermore, our findings are consistent with other papers. Dorn and Huberman (2005) also analyze a sample of online broker investors and find that wealthier investors place more trades but churn over their portfolio less frequently, other things equal. Vissing-Jorgensen (2003) analyzes the 1998 and the 2001 Survey of Consumer Finances and finds that wealthier investors make much more trades than less wealthy investors.

Again, both past market returns and past portfolio returns are significantly positively related to the number of transactions and the effect of past market returns is stronger.

As the number of stock transactions has only non negative integer values, count data models are appropriate to analyze the data set. As the number of stock transactions is overdispersed (the variance $(32,523)$ exceeds the mean (105)), Poisson regression models are inappropriate. The reason is that Poisson regression models assume equality of conditional mean and variance. We thus use random (Regression (10)) and fixed effects (regression (11)) negative binomial panel regressions in Table 5 (see, for example, Winkelmann (2003) for details). The dependent variable is the number of stock transactions in a given month. In the negative binomial regression model, which is obtained by introducing unobserved heterogeneity into the Poisson model, the negative binomial distribution provides the probability of the number of event occurrences (the number of transactions in our case). This distribution allows for overdispersion. The findings strengthen our previous results. Both past market returns as well as past portfolio returns affect trading volume 
but the effect for past market returns is stronger. Note, that in negative binomial fixed effects panel regressions, time-invariant variables do not drop out, as "random effects" and "fixed effects" refer to the distribution of the dispersion parameter (see, for example, Winkelmann (2003)).

The last regression in Table 5 presents a pooled Logit regressions. The dependent variable is an indicator variable that takes the value 1 if the investor trades in a given month and 0 otherwise. Explanatory variables are similar to those analyzed in the regressions discussed before. The results of this regression strengthen our previous findings. Past market returns as well as past portfolio performance have a positive effect on the propensity to trade. The other explanatory variables have the expected sign. Like Grinblatt and Keloharju (2001), we also ran the less sensible OLS specification (linear probability model). The results are similar.

\subsection{Robustness Checks}

Table 5 contains several robustness checks of our results. The table presents random and fixed effects ordinary least squares panel regressions. For brevity, we only present results for the logarithm of $(1+$ monthly stock portfolio turnover $)$ as dependent variable. The results are similar when we use other trading activity measures. The explanatory variables are similar to those analyzed in Table 5 with a few exceptions.

In Regressions (1) and (2), we also include past stock market and portfolio returns (one lag) as well as a dummy variable that is set equal to 1 if the own portfolio return was higher than the DAX return in the last month. Both lagged return variables remain significant. Trading activity is especially higher when past portfolio performance was higher than the market return which comfirms overconfidence stories based on biased self-attribution.

In Regressions (3) and (4), we include past stock market and portfolio returns (one lag) as well as the respective returns over the previous six months. Several other authors also analyze the effects of past returns over longer horizons (see, for example, Nicolosi, Peng, and Zhu (2007) or Statman, Thorley, and Vorkink (2006)). Note, however, that overconfidence models are not very precise on how we should specify the lag length in empirical studies. In Regressions (3) and (4), we include returns over the previous six 
months as Statman, Thorley, and Vorkink (2006) find that returns that are lagged more than 6 months do not significantly affect trading activity anymore. Furthermore, Grinblatt and Keloharju (2000) find that returns more than six months in the past have very little effect on the buy ratios of investors. In our regressions, both past long-horizon market as well as portfolio returns significantly affect trading activity. We are thus able to confirm our prior results as well as other studies. ${ }^{20}$

In Regressions (5) and (6), we follow the approach of Chordia, Huh, and Subrahmanyam (2007) and split past stock market and portfolio returns (one lag) in two return variables each. "return $(+)$ " is the monthly return if positive and 0 otherwise. "return (-)" is the monthly return if negative and 0 otherwise. Chordia, Huh, and Subrahmanyam (2007) study cross-sectional variations in trading activity for a sample of NYSE/AMEX and Nasdaq stocks. They find (among other things) that their lagged "stock return (+)" variable positively affects subsequent stock turnover whereas their "stock return (-)" variable negatively affects subsequent stock turnover. They interpret this finding in the way that the disposition effect does not seem to be an important determinant of trading activity in their aggregate data. In contrast, we find that our "return (-)" also positively affects trading activity. However, this is no surprise as Weber and Welfens (2007) show for our investor sample, that our investors are indeed prone to the disposition effect.

In Tables 7 and 8, we further analyze the robustness of our results. We analyze whether the degree of investor activeness (as measured by average turnover over the sample period and the number of active months), age, or investment experience influence the past-returnstrading-volume-link. That these measures affect trading behavior is often argued (see Calvet, Campbell, and Sodini (2007) or Korniotis and Kumar (2007) as recent examples). However, we find that the past-returns-trading-volume-link does not depend on investor activeness, age, or investment experience.

Furthermore, in unreported results, we find that our regression results are robust. They hold for different sets of explanatory results. In particular, the omission of the investment experience and the age variable (which increases the number of observations) and the

\footnotetext{
${ }^{20}$ In other regression specifications, we include six past return variables, one for each month. Such a specification is, for example, used by Chen, Hong, and Stein (2001), who explain skewness of stock returns by several lags of past returns. When we use such as specification, our results are similar.
} 
inclusion of the income variable (which decreases the number of observations) or a gender dummy do not alter our main results. In general, we do not include the gender dummy variable due to the fact that we almost only have a male investor sample (see Table 1).

\section{Evaluation of Alternative Explanations}

In the previous subsection we showed that both past market returns as well as own past realized portfolio performance drive trading activity. Both findings are consistent with overconfidence models. However, there are several other theoretical explanations that predict a link between past returns affect trading activity. We will discuss these explanations in turn. A summary of some of these explanation is, for example, provided by Griffin, Nardari, and Stulz (2007), Table 3. Further explanations are also discussed in Chordia, Huh, and Subrahmanyam (2007) and Brunnermeier (2001).

Our strategy to disentangle these competing theories with often similar predictions is as follows. We first evaluate existing theories and extract which past return variable drives trading activity in the respective theory. After that, we identify the predictions of the respective theory concerning the risk of stocks purchased and the degree of (under-) diversification afterwards. We summarize these results in Table 9.

Remember from the introduction and Section 2 that high past market returns can make investors overconfident in the way that they underestimate the risk of stock returns. As a result, predictions intervals are too tight or stock return volatility is underestimated. This facet of overconfidence is often called "miscalibration" (see also Glaser, Nöth, and Weber (2004), Glaser and Weber (2007), Hilton (2001), or Lichtenstein, Fischhoff, and Phillips (1982)). As a consequence, investors trade more actively and engage in higher risk.

High past portfolio returns make investors overconfident in the way that they think that they are above average traders. One reason can be biased self-attribution. Note that such a self-attribution story does not work with high past market returns. Investors will not attribute high past market returns to their skill but only high own past realized portfolio returns. As a consequence, investors also trade more actively and engage in higher risk.

Other potential explanations for a positive past-return-volume-link are: 
Portfolio rebalancing needs. Informed investors trade to take advantage of information they have and to rebalance their portfolio (Wang (1994), He and Wang (1995)). This explanation predicts a positive correlation between lagged portfolio returns and trading activity, but not between past portfolio returns and risk taking.

Participation, awareness, and trust in stock market. Costs to participate in the stock market may also serve as an explanation for the link between past returns and trading volume. For instance, in the model of Orosel (1998), high stock returns lead investors who do not participate in the stock market to increase their estimate of the profitability of stock market participation. In equilibrium, market participation rises after a share price increase and falls after a drop. High past returns can also increase the awareness (Guiso and Jappelli (2005)) and trust in the stock market (Guiso, Sapienza, and Zingales (2007)) and thus stock market participation. This explanation predicts a positive correlation between lagged market returns and trading activity, but not between past market returns and risk taking.

Disposition effect. Odean (1998a) finds that investors show a strong preference for realizing winners rather than losers. This finding is called the disposition effect, the tendency to sell winners too early and ride losers too long. ${ }^{21}$ The disposition effect implies that volume follows returns because investors are reluctant to trade after poor returns and eager to lock in gains after stock price increases. There is no prediction for a link between portfolio returns and risk taking.

Differences of opinion. Theoretically, differences of opinion can arise due to differences in prior beliefs or due to differences in the way investors interpret public information. Modeling differences of opinion is mainly motivated by mere plausibility: differences of opinion are present in every day life (see, for example, Harris and Raviv (1993)). Varian (1989), Harris and Raviv (1993), and Kandel and Person (1995) show that differences of opinion help explain high levels of trading volume and that a higher degree of differences of opinion leads to a higher degree of trading volume. There are studies which show empirically that differences in opinion creates trading volume. Bamber, Barron, and Stober (1999) and Antweiler and Frank (2004) are two examples. Bamber, Barron, and Stober

\footnotetext{
${ }^{21}$ See Shefrin and Statman (1985) and Weber and Camerer (1998) for further empirical and experimental evidence on the disposition effect.
} 
(1999) measure differential interpretations using data on analysts' revisions of forecasts of annual earnings after the announcement of quarterly earnings. They find that differential interpretations explain a significant amount of trading. Antweiler and Frank (2004) study the effect of more than 1.5 million messages posted on Yahoo! Finance and Raging Bull about the 45 companies in the Dow Jones Industrial Average and the Dow Jones Internet Index. They find that disagreement among the posted Internet messages is associated with increased trading volume. In their survey of CFO stock return expectations, Graham and Harvey (2003) show that past market returns are related to differences of opinion. They show that high past absolute returns lead to higher differences of opinion. Although Graham and Harvey (2003) find that both large negative and positive returns affect differences of opinion, we argue that negative returns that are associated with differences of opinion do not lead to the same level of trading activity as positive returns in connection with differences of opinion. Negative returns are associated with paper losses and investors usually are reluctant to realize these paper losses. ${ }^{22}$ To summarize: High past market returns can increase disagreement among investors. As a consequence, investors trade more. However, there is not prediction concerning risk taking.

Table 9 summarizes the predictions of these theories. Before we start to test the predictions concerning the risk of stocks purchased and the degree of (under-) diversification after high returns, we briefly evaluate the explanations. It is unlikely that our small individual investors have private information that are often a key ingredient of portfolio rebalancing models. Participation, awareness, and trust stories do also not apply to our investor sample. All investors in our data set hold stocks at least once during our sample period from January 1997 to March 2001. Furthermore, they had opened their account before January 1997. Thus they were aware of the stock market in times in which stock market participation in Germany was low compared to, for example, the U.S.. Participation, awareness, and trust stories are more appropriate for investors that invested in the stock market after the boom years in the year 2000 for the first time and can thus explain why aggregate trading volume increased until the year 2000. Furthermore, participation, awareness, and trust stories do not predict that investors buy riskier stocks after high returns. Thus, only overconfidence theories predict that overconfident investors underdiversify or buy respectively hold high-risk securities (see, for example, the theoretical

\footnotetext{
${ }^{22}$ See Shefrin and Statman (1985), Odean (1998a), and Weber and Camerer (1998).
} 
models in Odean (1998b) or Daniel, Hirshleifer, and Subrahmanyam (1998)).

Kim and Nofsinger (2007) analyze these predictions of overconfidence models by analyzing preferences for stocks in the bull and the bear market in Japan. They especially analyze whether the risk of stocks bought (as measured by the volatility of returns) or the market-to-book ratio are different between market conditions. Chen, Kim, Nofsinger, and Rui (2007) analyze, for example, the determinants of the number of stocks in the portfolios of Chinese investors. Chuang and Lee (2006) analyze whether overconfident investors underestimate risk and trade more in riskier securities using market level data from the U.S.. Barber and Odean (2000) analyze whether men who are regarded as more overconfident then women trade (among other things) stocks with a higher standard deviation of returns.

We follow the approach of the above mentioned studies and analyze whether investors in our data set buy stocks with higher market-to-book ratios, higher volatility of returns or smaller stocks following positive returns. Furthermore, we analyze whether the number of stocks in a portfolio changes after high returns in the past. ${ }^{23}$

Table 10 presents the results. High past market returns do not lead to more risk taking. The opposite is true for investors with high portfolio returns in the past. Investors with high past portfolio returns buy stocks with high book-to-market ratios (Regressions (1) and (2)) and high standard deviation of stock returns (Regressions (3) and (4)). Furthermore, they reduce the number of stocks in the portfolio after high portfolio returns in the past (see Regression (7)). These results are only consistent with an overconfidence theory based on biased self-attribution and with differences of opinion explanations of high trading volume as Table 9 shows.

\section{Discussion and Conclusion}

In this study, we analyze a panel data set of individual investors who have discount broker accounts over a 51 month period using cross-sectional time-series regression models

\footnotetext{
${ }^{23}$ This part of our study is thus similar to studies analyzing stock preferences of investors. Similar studies are, for example, Dahlquist and Robertsson (2001) and Ng and Wu (2006) and the references cited therein.
} 
to investigate the relationship between past returns and trading volume. We find that both past market returns and past portfolio returns affect trading volume of individual investors. As several explanations predict a positive link between past returns and trading activity as well, we analyzed in a next step whether high returns affect risk taking of investors. Only high past portfolio returns lead to higher risk taking. High past market returns are not associated with higher risk taking afterwards.

These results can be interpreted as follows. High past portfolio returns make investors overconfident due to a self-attribution bias. They feel overconfident in the sense that they think to be better investors than others. High past market returns could potentially make investors overconfident in the sense that they underestimate the volatility of stock returns. As a result, prediction intervals would be too tight. While such a story is consistent with a positive past-market-return-trading-volume-link, it is not consistent anymore with the fact that high past market returns do not lead to more risk taking. It is however possible that high past market returns just influence disagreement or differences of opinion among investors which does not necessarily affect the degree of risk taking of investors.

These results are consistent with other recent studies. Glaser and Weber (2007) correlate individual overconfidence scores (miscalibration, volatility estimates, better than average effect) with several measures of trading volume of individual investors. They find that investors who think that they are above average in terms of investment skills or past performance (but who did not have above average performance in the past) trade more. Measures of miscalibration are unrelated to measures of trading volume. These results are also consistent with overconfidence stories based on biased self-attribution and with differences of opinion explanations of trading volume. Their findings can be regarded as a psychological foundation of differences of opinion models. An investor who regards himself as above average is more likely to maintain a specific opinion about the future performance of an asset even though he knows that other investors or the market hold a different opinion. Note, that this difference of opinion is the source of volume in the "differences of opinion" literature. Hales (2005) provides experimental evidence that a willingness to engage in speculative trade is largely driven by a failure to account for information about value implicit in other trader's actions. Unlike overconfidence models, which focus on erroneous estimates of signal precision, these participants do not trade too 
much because they underestimate the error of noisy signals. Rather, participants engage in too much speculative trade because they tend not to think about the implications of disagreement. The results documented in Hales (2005) present evidence in favor of the general technique of modeling investor behavior using differences of opinion by showing that, even though traders are capable of adjusting for other's behavior, they will not naturally do so. He also argues that, as a result, investors might often act like they believe they are better than average traders (or have better than average information).

Based on the results and studies discussed in this paper and based on several other findings, Hong and Stein (2007) write in their recent survey that "if behavioral finance is ever to approach the stature of classical asset pricing, it will have to move beyond being a large collection of empirical facts and competing one-off models, and ultimately reach a similar sort of consensus." While many behavioral finance theories are running a horse race to best explain a large set of findings, they argue that "disagreement models ... represent the best horse on which to bet. Disagreement models uniquely hold the promise of being able to deliver a comprehensive joint account of stock prices and trading volume, which we consider to be one of the highest priorities for theoretical work in asset pricing." 


\section{References}

Agnew, J., 2005, "An Analysis of How Individuals React to Market Returns in One 401(k) Plan," Working paper, The College of William and Mary.

Antweiler, W., and M. Z. Frank, 2004, "Is All That Talk Just Noise? The Information Content of Internet Stock Message Boards," Journal of Finance, 59(3), 1259 - 1294.

Atkinson, A., 1985, Plots, Transformations, and Regression. Clarendon Press.

Baltagi, B. H., 2001, Econometric analysis of panel data. Wiley.

Bamber, L. S., O. E. Barron, and T. L. Stober, 1999, "Differential Interpretations and Trading Volume," Journal of Financial and Quantitative Analysis, 34(3), 369-386.

Barber, B. M., and T. Odean, 2000, "Trading is Hazardous to Your Wealth: The Common Stock Investment Performance of Individual Investors," Journal of Finance, 55, 773806.

—_ 2001, "Boys Will Be Boys: Gender, Overconfidence, And Common Stock Investment," Quarterly Journal of Economics, 116(1), 261-292.

— , 2002, "Online Investors: Do the Slow Die First?," Review of Financial Studies, $15(2), 455-487$.

Benos, A. V., 1998, "Aggressiveness and survival of overconfident traders," Journal of Financial Markets, 1, 353-383.

Brunnermeier, M. K., 2001, Asset Pricing under Asymmetric Information: Bubbles, Crashes, Technical Analysis, and Herding. Oxford University Press.

Caballé, J., and J. Sákovics, 2003, "Speculating against an overconfident market," Journal of Financial Markets, 6, 199-225.

Calvet, L. E., J. Y. Campbell, and P. Sodini, 2007, "Fight or Flight? Portfolio Rebalancing by Individual Investors," Working paper, Harvard University.

Chen, G.-M., K. A. Kim, J. R. Nofsinger, and O. M. Rui, 2007, "Trading Performance, Disposition Effect, Overconfidence, Representativeness Bias, and Experience of Emerging Market Investors," Journal of Behavioral Decision Making, pp. -, forthcoming. 
Chen, J., H. Hong, and J. C. Stein, 2001, "Forecasting crashes: trading volume, past returns, and conditional skewness in stock prices," Journal of Financial Economics, $61(3), 345-381$.

Choe, H., B.-C. Kho, and R. Stulz, 1999, "Do foreign investors destabilize stock markets? The Korean experience in 1997," Journal of Financial Economics, 54, 227-264.

Chordia, T., S.-W. Huh, and A. Subrahmanyam, 2007, "The Cross-Section of Expected Trading Activity," Review of Financial Studies, 20(3), 709-740.

Chuang, W.-I., and B.-S. Lee, 2006, "An empirical evaluation of the overconfidence hypothesis," Journal of Banking and Finance, 30(9), 2489-2515.

Dahlquist, M., and G. Robertsson, 2001, "Direct foreign ownership, institutional investors, and firm characteristics," Journal of Financial Economics, 59(3), 413-440.

Daniel, K., D. Hirshleifer, and A. Subrahmanyam, 1998, "Investor Psychology and Security Market Under- and Overreactions," Journal of Finance, 53(6), 1839-1885.

Davidson, R., and J. G. MacKinnon, 1993, Estimation and Inference in Econometrics. Oxford University Press.

Deaves, R., E. Lüders, and M. Schröder, 2007, "The Dynamics of Overconfidence: Evidence from Stock Market Forecasters," Working paper, Center for European Economic Research (ZEW), Mannheim.

Diamond, D. W., and R. E. Verrecchia, 1981, "Information aggregation in a noisy rational expectations economy," Journal of Financial Economics, 9, 221-235.

Dorn, D., and G. Huberman, 2005, "Talk and Action: What Individual Investors Say and What They Do," Review of Finance, 9, 437-481.

—_ 2007, "Turnover and Volatility," Working paper, Drexel University and Columbia University.

Gervais, S., and T. Odean, 2001, "Learning to Be Overconfident," Review of Financial Studies, 14(1), 1-27.

Glaser, M., 2003, "Online Broker Investors: Demographic Information, Investment Strategy, Portfolio Positions, and Trading Activity," SFB 504 discussion paper 03-18, University of Mannheim. 
Glaser, M., M. Nöth, and M. Weber, 2004, "Behavioral Finance," in Blackwell Handbook of Judgment and Decision Making, ed. by D. J. Koehler, and N. Harvey. Blackwell, Malden, Mass., pp. 527-546.

Glaser, M., and M. Weber, 2007, "Overconfidence and Trading Volume," Geneva Risk and Insurance Review, pp. -, forthcoming.

Graham, J. R., and C. R. Harvey, 2003, "Expectations of equity risk premia, volatility and asymmetry," Working paper, Fuqua School of Business, Duke University.

Greene, W. H., 2003, Econometric analysis. Prentice Hall, Upper Saddle River, NJ.

Griffin, J. M., F. Nardari, and R. M. Stulz, 2007, "Do Investors Trade More When Stocks Have Performed Well? Evidence from 46 Countries," Review of Financial Studies, 20(3), 905-951.

Grinblatt, M., and M. Keloharju, 2000, "The investment behavior and performance of various investor types: a study of Finland's unique data set," Journal of Financial Economics, 55, 43-67.

— , 2001, "What Makes Investors Trade?," Journal of Finance, 56(2), 589-616.

—— , 2006, "Sensation Seeking, Overconfidence, and Trading Activity," Working paper, University of.

Grossman, S. J., and J. E. Stiglitz, 1980, "On the impossibility of informationally efficient markets," American Economic Review, 70, 393-408.

Guiso, L., and T. Jappelli, 2005, "Awareness and Stock Market Participation," Review of Finance, 9(4), 537-567.

Guiso, L., P. Sapienza, and L. Zingales, 2007, "Trusting the Stock Market," European Corporate Governance Institute - Finance Working Paper No. 170/2007.

Hales, J., 2005, "Are Investors Really Willing to Agree to Disagree? An Experimental Investigation of How Disagreement and Attention to Disagreement Affect Trading Volume," Working paper, University of Texas at Austin.

Harris, M., and A. Raviv, 1993, "Differences of Opinion Make a Horse Race," Review of Financial Studies, 6(3), 473-506. 
He, H., and J. Wang, 1995, "Differential Information and Dynamic Behavior of Stock Trading Volume," Review of Financial Studies, 8(4), 919-972.

Hellwig, M. F., 1980, "On the aggregation of information in competitive markets," Journal of Economic Theory, 22, 477-498.

Hilary, G., and L. Menzly, 2006, "Does Past Success Lead Analysts to Become Overconfident?," Management Science, 52(4), 489-500.

Hilton, D. J., 2001, "The Psychology of Financial Decision-Making: Applications to Trading, Dealing, and Investment Analysis," Journal of Psychology and Financial Markets, $2(1), 37-53$.

Hirshleifer, D., 2001, "Investor Psychology and Asset Pricing," Journal of Finance, 56(4), $1533-1597$.

Hong, H., and J. C. Stein, 2007, "Disagreement and the Stock Market," Journal of Economic Perspectives, 21(2), 109-128.

Kandel, E., and N. D. Pearson, 1995, "Differential Interpretation of Public Signals and Trade in Speculative Markets," Journal of Political Economy, 103(4), 831-872.

Kim, K. A., and J. R. Nofsinger, 2007, "The behavior of individual investors in Japan during bull and bear markets," Journal of Behavioral Finance, pp. -, forthcoming.

Korniotis, G., and A. Kumar, 2007, "Does Investment Skill Decline due to Cognitive Aging or Improve with Experience?," Working paper, McCombs School of Business, University of Texas at Austin.

Kyle, A. S., 1985, "Continuous Auctions and Insider Trading," Econometrica, 53(6), 13151336.

— , 1989, "Informed Speculation with Imperfect Competition," Review of Economic Studies, 56, 317-356.

Kyle, A. S., and F. A. Wang, 1997, "Speculation Duopoly with Agreement to Disagree: Can Overconfidence Survive the Market Test?," Journal of Finance, 52(5), 2073-2090.

Langer, E. J., and J. Roth, 1975, "Heads I Win, Tail It's Chance: The Illusion of Control as a Function of the Sequence of Outcomes in a Purely Chance Task," Journal of Personaliy and Social Psychology, 32(6), 951-955. 
Lichtenstein, S., B. Fischhoff, and L. D. Phillips, 1982, "Calibration of probabilities: The state of the art to 1980," in Judgment under uncertainty: Heuristics and Biases, ed. by D. Kahneman, P. Slovic, and A. Tversky. Cambridge University Press, pp. 306-334.

Miller, D. T., and M. Ross, 1975, "Self-serving biases in the attribution of causality: Fact or fiction?," Psychological Bulletin, 82(2), 213-225.

Ng, L., and F. Wu, 2006, "Revealed stock preferences of individual investors: Evidence from Chinese equity markets," Pacific-Basin Finance Journal, 14(2), 175-192.

Nicolosi, G., L. Peng, and N. Zhu, 2007, "Do Individual Investors Learn from Their Trading Experience?," Working paper.

Odean, T., 1998a, "Are Investors Reluctant to Realize their Losses?," Journal of Finance, $53,1775-1798$.

— , 1998b, "Volume, Volatility, Price, and Profit When All Traders Are Above Average," Journal of Finance, 53(6), 1887-1934.

— , 1999, "Do Investors Trade Too Much?," American Economic Review, 89(5), $1279-1298$.

Orosel, G. O., 1998, "Participation Costs, Trend Chasing, and Volatility of Stock Prices," Review of Financial Studies, 11(3), 521-557.

Reinartz, W., J. Thomas, and V. Kumar, 2005, "Balancing Acquisition and Retention Resources to Maximize Customer Profitability," Journal of Marketing, 69, 63-79.

Schmitz, P., M. Glaser, and M. Weber, 2005, "Individual Investor Sentiment and Stock Returns - What Do We Learn from Individual Warrant Traders?," Working paper, University of Mannheim.

Schneider, D. J., A. H. Hastorf, and P. C. Ellsworth, 1979, Person Perception. AddisonWesley.

Shefrin, H., and M. Statman, 1985, "The Disposition to sell winners too Early and Ride Losers too Long: Theory and Evidence," Journal of Finance, 40, 777-790.

Spanos, A., 1986, Statistical foundations of econometric modelling. Cambridge University Press. 
Statman, M., S. Thorley, and K. Vorkink, 2006, "Investor Overconfidence and Trading Volume," Review of Financial Studies, 19, 1531-1565.

Varian, H. R., 1989, "Differences of Opinion in Financial Markets," in Financial Risk: Theory, Evidence, and Implications, ed. by C. C. Stone. Kluwer, pp. 3-37.

Vissing-Jorgensen, A., 2003, "Perspectives on Behavioral Finance: Does "Irrationality" Disappear with Wealth? Evidence from Expectations and Actions," NBER Macroeconomics Annual 2003, pp. 139-194.

Wang, F. A., 1998, "Strategic trading, asymmetric information and heterogeneous prior beliefs," Journal of Financial Markets, 1, 321-352.

Wang, J., 1994, "A Model of Competitive Stock Trading Volume," Journal of Political Economy, 102(1), 127-168.

Weber, M., and C. Camerer, 1998, "The Disposition Effect in Securities Trading: Experimental Evidence," Journal of Economic Behavior and Organization, 33, 167-184.

Weber, M., and F. Welfens, 2007, "An Individual Level Analysis of the Disposition Effect: Empirical and Experimental Evidence," Working paper, University of Mannheim.

Winkelmann, R., 2003, Econometric analysis of count data. Springer.

Wolosin, R. J., S. J. Sherman, and A. Till, 1973, "Effects of Cooperation and Competition on Responsibility Attribution After Success and Failure," Journal of Experimental Social Psychology, 9, 220-235.

Wooldridge, J. M., 2002, Econometric Analysis of Cross Section and Panel Data. MIT Press.

Zeithaml, V. A., R. T. Rust, and K. N. Lemon, 2001, "The Customer Pyramid: Creating and Serving Profitable Customers," California Management Review, 43(4), 118-142. 
Table 1: Descriptive Statistics of Investor Sample

This table shows descriptive statistics of the age, the stock market investment experience (in years), the number of transactions in all security categories (sum over the period from January 1997 to mid April 2001), the number of stock transactions (sum over the period from January 1997 to mid April 2001), the number of warrant transactions (sum over the period from January 1997 to mid April 2001), the average of the monthly stock portfolio value (in EUR), the number of stocks in portfolio (time series average across investors), income (in EUR), the average of the monthly stock portfolio turnover from January 1997 to March 2001, the average of the monthly stock portfolio performance (see Section 3 for details), the percentage of investors who describe their investment strategy as high-risk, the percentage of investors who use their account for retirement savings, and the percentage of female investors in our investor sample. The table contains means and medians of these variables as well as the number of observations of the respective variable. Income is reported within five ranges, where the top range is more than 102,258.38 EUR (200,000 Deutsche Mark (DEM)). We calculate means and medians using the midpoint of each range and 115,040.67 EUR (225,000 DEM) for the top range. Investment experience is reported within five ranges, where the top range is more than 15 years. We calculate means and medians using the midpoint of each range and 17.5 years for the top range. We exclude investors with less than 5 turnover observations to calculate the average of the monthly stock portfolio turnover and we exclude investors with stock positions in 12 or fewer months to calculate the average of the monthly stock portfolio performance.

\begin{tabular}{|c|c|c|}
\hline No. of accounts & & 3,079 \\
\hline \multirow[t]{3}{*}{ Age } & Mean & 40.86 \\
\hline & Median & 39 \\
\hline & Observations & 2,552 \\
\hline \multirow[t]{3}{*}{ Investment experience } & Mean & 5.50 \\
\hline & Median & 7.5 \\
\hline & Observations & 2,386 \\
\hline \multirow[t]{3}{*}{ Transactions } & Mean & 182.89 \\
\hline & Median & 103 \\
\hline & Observations & 3,079 \\
\hline \multirow[t]{3}{*}{ Stock transactions } & Mean & 105.45 \\
\hline & Median & 54 \\
\hline & Observations & 2,998 \\
\hline \multirow[t]{3}{*}{ Warrant transactions } & Mean & 87.60 \\
\hline & Median & 27 \\
\hline & Observations & 1,650 \\
\hline \multirow[t]{3}{*}{ Stock portfolio value (EUR) } & Mean & $36,622.87$ \\
\hline & Median & $15,679.79$ \\
\hline & Observations & 2,964 \\
\hline \multirow{3}{*}{ Number of stocks in portfolio } & Mean & 6.76 \\
\hline & Median & 5.17 \\
\hline & Observations & 2,964 \\
\hline \multirow[t]{3}{*}{ Income (EUR) } & Mean & $52,149.05$ \\
\hline & Median & $38,346.89$ \\
\hline & Observations & 1,128 \\
\hline \multirow[t]{3}{*}{ Stock portfolio turnover } & Mean & 1.36 \\
\hline & Median & 0.33 \\
\hline & Observations & 2,874 \\
\hline \multirow[t]{3}{*}{ Stock portfolio performance } & Mean & 0.0054 \\
\hline & Median & 0.0057 \\
\hline & Observations & 2,793 \\
\hline High risk investment strategy & $\%$ & 12.02 \\
\hline Retirement savings & $\%$ & 3.73 \\
\hline Female investors & $\%$ & 4.81 \\
\hline
\end{tabular}




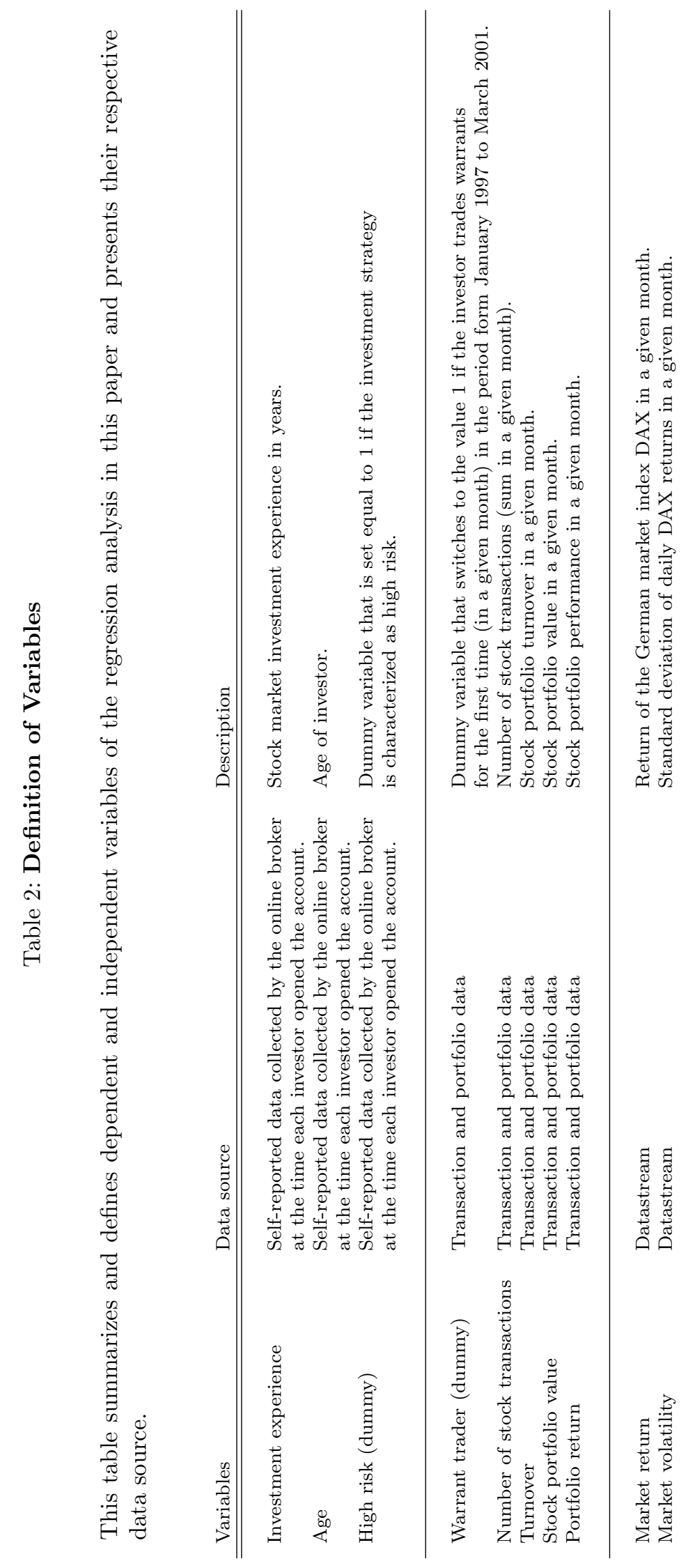




\section{Table 3: Firm Characteristics of Stocks Traded}

This table presents mean, median, the 25 th percentile, the 75 th percentile, and the number of observations per variable (firm months) of several characteristics (average daily stock returns, volatility, unadjusted price, monthly trading volume, market capitalization, market to book ratio, dividend yield) of the more than 4,000 stocks traded by the investors in our data set. To calculate mean, median, and percentiles, we include the monthly observation of a stock only when the stock is traded or held in a portfolio in that month. Data on firms is obtained from Datastream.

\begin{tabular}{|c|c|c|c|c|c|}
\hline & $\begin{array}{l}\text { Observations } \\
\text { (firm months) }\end{array}$ & Mean & $\begin{array}{c}25 \mathrm{th} \\
\text { percentile }\end{array}$ & median & $\begin{array}{c}75 \text { th } \\
\text { percentile }\end{array}$ \\
\hline Average daily stock returns & 66,904 & 0.0073 & -0.0036 & 0.0000 & 0.0039 \\
\hline Volatility (standard deviation of daily returns) & 66,903 & 0.0686 & 0.0177 & 0.0283 & 0.0460 \\
\hline Unadjusted price (in EUR) & 62,744 & 85.75 & 8.91 & 24.98 & 65.74 \\
\hline Monthly trading volume (in million EUR) & 62,060 & 419.38 & 0.00 & 6.40 & 102.10 \\
\hline Market capitalization (in million EUR) & 45,678 & 8545.19 & 158.90 & 1178.17 & 7520.68 \\
\hline Market to book ratio & 19,940 & 3.87 & 1.42 & 2.32 & 4.32 \\
\hline Dividend yield & 47,174 & 1.79 & 0.00 & 1.14 & 2.65 \\
\hline
\end{tabular}

Table 4: Correlation of Key Variables

This table presents correlation coefficients and adjusted significance levels (in parentheses) of key variables. To calculate the correlation coefficients, we use monthly data of $\ln (1+$ turnover $)$, the market return ( $\operatorname{lag} 1$ ), the portfolio return (lag 1), the logarithm of the average market-to-book ratio of stocks purchased in a given month, the average standard deviation of daily returns of stocks purchased in a given month, the logarithm of the average market capitalization of stocks purchased in a given month, and the number of stocks in investors' portfolios in a given month. Before averaging, the market-to-book ratio, the standard deviation of daily returns, and the market capitalization of stocks traded are winsorized at the 1 percent level. * indicates significance at $1 \%$.

\begin{tabular}{|c|c|c|c|c|c|c|c|c|}
\hline & & $(1)$ & $(2)$ & (3) & $(4)$ & $(5)$ & $(6)$ & $(7)$ \\
\hline (1) & $\ln (1+$ turnover $)$ & 1 & & & & & & \\
\hline$(2)$ & Market return (lag 1$)$ & $\begin{array}{c}0.0676^{*} \\
(<0.0001)\end{array}$ & 1 & & & & & \\
\hline (3) & Portfolio return (lag 1$)$ & $\begin{array}{c}0.0688^{*} \\
(<0.0001)\end{array}$ & $\begin{array}{c}0.4654^{*} \\
(<0.0001)\end{array}$ & 1 & & & & \\
\hline (4) & $\begin{array}{l}\ln (\text { average market-to-book } \\
\text { ratio of purchased stocks) }\end{array}$ & $\begin{array}{c}0.0942^{*} \\
(<0.0001)\end{array}$ & $\begin{array}{l}-0.0077 \\
(0.9908)\end{array}$ & $\begin{array}{c}0.0486^{*} \\
(<0.0001)\end{array}$ & 1 & & & \\
\hline (5) & $\begin{array}{l}\text { Average standard deviation of daily } \\
\text { returns of purchased stocks }\end{array}$ & $\begin{array}{c}0.0334^{*} \\
(<0.0001)\end{array}$ & $\begin{array}{c}0.0146 \\
(0.0290)\end{array}$ & $\begin{array}{c}0.0498^{*} \\
(<0.0001)\end{array}$ & $\begin{array}{c}0.1896^{*} \\
(<0.0001)\end{array}$ & 1 & & \\
\hline (6) & $\begin{array}{l}\ln (\text { average market capitalization } \\
\text { of purchased stocks) }\end{array}$ & $\begin{array}{l}-0.0068 \\
(0.9637)\end{array}$ & $\begin{array}{l}-0.0349^{*} \\
(<0.0001)\end{array}$ & $\begin{array}{l}-0.0139 \\
(0.0705)\end{array}$ & $\begin{array}{c}0.1039 * \\
(<0.0001)\end{array}$ & $\begin{array}{l}-0.2115^{*} \\
(<0.0001)\end{array}$ & 1 & \\
\hline (7) & $\begin{array}{l}\text { Number of } \\
\text { stocks in portfolio }\end{array}$ & $\begin{array}{l}-0.0876^{*} \\
(<0.0001)\end{array}$ & $\begin{array}{l}-0.0593^{*} \\
(<0.0001)\end{array}$ & $\begin{array}{l}-0.0546^{*} \\
(<0.0001)\end{array}$ & $\begin{array}{l}0.0799^{*} \\
(<0.0001)\end{array}$ & $\begin{array}{l}0.0354^{*} \\
(<0.0001)\end{array}$ & $\begin{array}{l}0.1117^{*} \\
(<0.0001)\end{array}$ & 1 \\
\hline
\end{tabular}




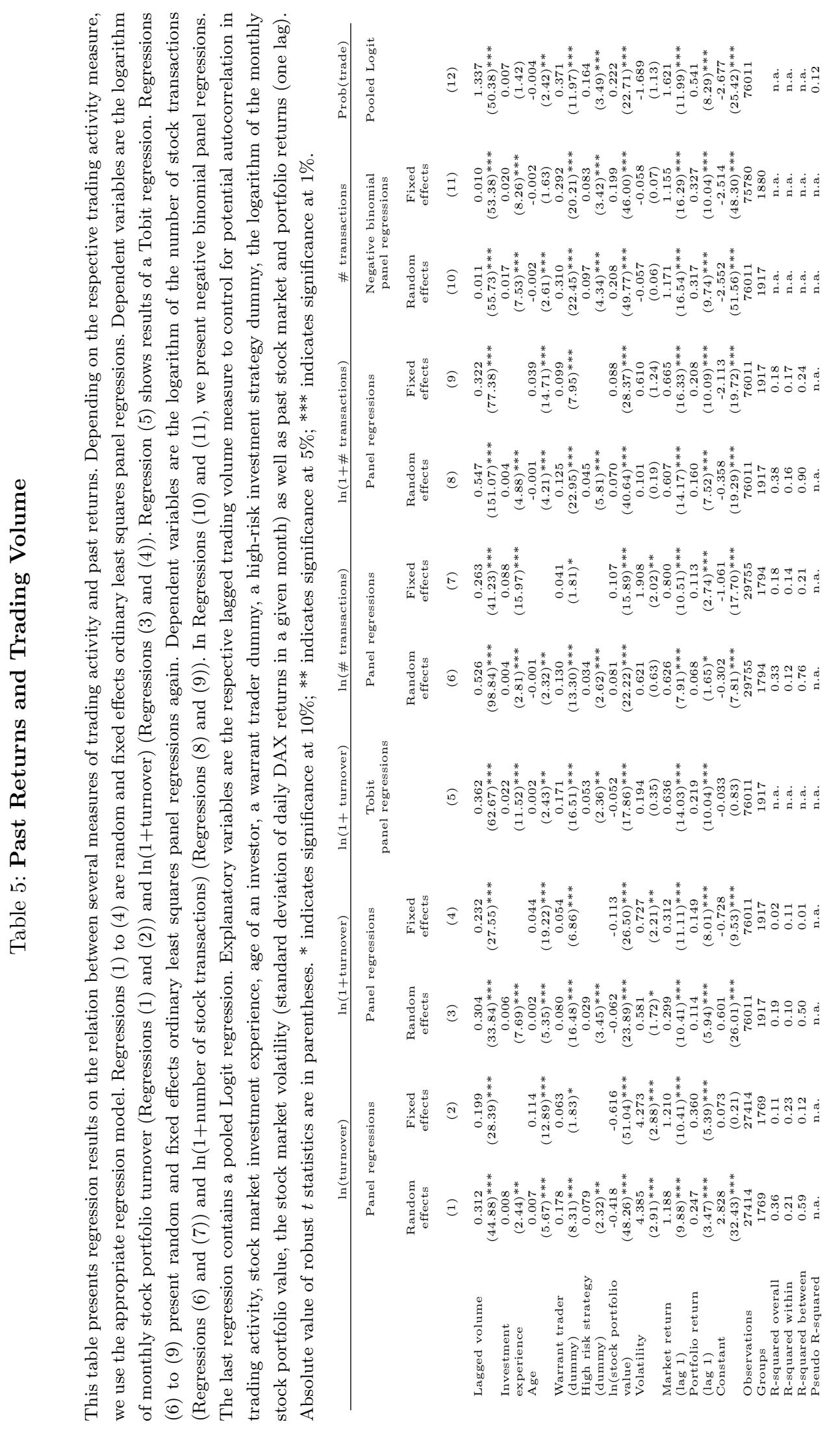




\section{Table 6: Past Returns and Trading Volume: Robustness}

This table presents random and fixed effects ordinary least squares panel regressions. Dependent variable is the logarithm of (1+ monthly stock portfolio turnover). Explanatory variables are the respective lagged trading volume measure to control for potential autocorrelation in trading activity, stock market investment experience, age of an investor, a warrant trader dummy, a high-risk investment strategy dummy, the logarithm of the monthly stock portfolio value and the stock market volatility (standard deviation of daily DAX returns in a given month). In Regressions (1) and (2), we also include past stock market and portfolio returns (one lag) as well as a dummy variable that is set equal to 1 if the own portfolio return was higher than the DAX return in the last month. In Regressions (3) and (4), we include past stock market and portfolio returns (one lag) as well as the respective returns over the previous six months. In Regressions (5) and (6), we split past stock market and portfolio returns (one lag) in two return variables each. "return (+)" is the monthly return if positive and 0 otherwise. "return (-)" is the monthly return if negative and 0 otherwise. Absolute value of robust $t$ statistics are in parentheses. * indicates significance at $10 \%$; ** indicates significance at $5 \% ; * * *$ indicates significance at $1 \%$.

\begin{tabular}{|c|c|c|c|c|c|c|}
\hline & $\begin{array}{l}\text { Random } \\
\text { effects }\end{array}$ & $\begin{array}{l}\text { Fixed } \\
\text { effects }\end{array}$ & $\begin{array}{l}\text { Random } \\
\text { effects }\end{array}$ & $\begin{array}{l}\text { Fixed } \\
\text { effects }\end{array}$ & $\begin{array}{l}\text { Random } \\
\text { effects }\end{array}$ & $\begin{array}{l}\text { Fixed } \\
\text { effects }\end{array}$ \\
\hline & (1) & $(2)$ & $(3)$ & $(4)$ & (5) & (6) \\
\hline Lagged volume & $\begin{array}{c}0.305 \\
(33.98)^{* * *}\end{array}$ & $\begin{array}{c}0.232 \\
(27.56)^{* * *}\end{array}$ & $\begin{array}{c}0.409 \\
(37.63)^{* * *}\end{array}$ & $\begin{array}{c}0.243 \\
(23.95)^{* * *}\end{array}$ & $\begin{array}{c}0.304 \\
(33.88)^{* * *}\end{array}$ & $\begin{array}{c}0.232 \\
(27.54)^{* * *}\end{array}$ \\
\hline Investment experience & $\begin{array}{c}0.006 \\
(7.65)^{* * *}\end{array}$ & & $\begin{array}{c}0.003 \\
(5.18)^{* * *}\end{array}$ & $\begin{array}{c}0.044 \\
(17.56)^{* * *}\end{array}$ & $\begin{array}{c}0.006 \\
(7.39)^{* * *}\end{array}$ & $\begin{array}{c}0.000 \\
(.)\end{array}$ \\
\hline Age & $\begin{array}{c}0.002 \\
(5.33)^{* * *}\end{array}$ & $\begin{array}{c}0.044 \\
(19.26)^{* * *}\end{array}$ & $\begin{array}{c}0.001 \\
(3.85)^{* * *}\end{array}$ & & $\begin{array}{c}0.002 \\
(5.39)^{* * *}\end{array}$ & $\begin{array}{c}0.045 \\
(19.48)^{* * *}\end{array}$ \\
\hline Warrant trader (dummy) & $\begin{array}{c}0.080 \\
(16.59)^{* * *}\end{array}$ & $\begin{array}{c}0.054 \\
(6.87)^{* * *}\end{array}$ & $\begin{array}{c}0.062 \\
(16.80)^{* * *}\end{array}$ & $\begin{array}{c}0.054 \\
(6.33)^{* * *}\end{array}$ & $\begin{array}{c}0.079 \\
(16.36)^{* * *}\end{array}$ & $\begin{array}{c}0.054 \\
(6.83)^{* * *}\end{array}$ \\
\hline High risk strategy (dummy) & $\begin{array}{c}0.029 \\
(3.49)^{* * *}\end{array}$ & & $\begin{array}{c}0.028 \\
(4.79)^{* * *}\end{array}$ & & $\begin{array}{c}0.029 \\
(3.44)^{* * *}\end{array}$ & $\begin{array}{c}0.000 \\
(.)\end{array}$ \\
\hline $\ln$ (stock portfolio value) & $\begin{array}{c}-0.062 \\
(23.87)^{* * *}\end{array}$ & $\begin{array}{c}-0.113 \\
(26.48)^{* * *}\end{array}$ & $\begin{array}{c}-0.039 \\
(18.59)^{* * *}\end{array}$ & $\begin{array}{c}-0.112 \\
(22.21)^{* * *}\end{array}$ & $\begin{array}{c}-0.062 \\
(23.80)^{* * *}\end{array}$ & $\begin{array}{c}-0.113 \\
(26.59)^{* * *}\end{array}$ \\
\hline Volatility & $\begin{array}{c}0.621 \\
(1.83)^{*}\end{array}$ & $\begin{array}{c}0.765 \\
(2.32)^{* *}\end{array}$ & $\begin{array}{c}1.062 \\
(2.97)^{* * *}\end{array}$ & $\begin{array}{c}1.106 \\
(3.23)^{* * *}\end{array}$ & $\begin{array}{l}0.443 \\
(1.22)\end{array}$ & $\begin{array}{c}0.463 \\
(1.31)\end{array}$ \\
\hline Market return (lag 1) & $\begin{array}{c}0.339 \\
(9.56)^{* * *}\end{array}$ & $\begin{array}{c}0.351 \\
(10.12)^{* * *}\end{array}$ & $\begin{array}{c}0.282 \\
(8.53)^{* * *}\end{array}$ & $\begin{array}{c}0.224 \\
(7.19)^{* * *}\end{array}$ & & \\
\hline Portfolio return (lag 1) & $\begin{array}{c}0.083 \\
(3.25)^{* * *}\end{array}$ & $\begin{array}{c}0.119 \\
(4.79)^{* * *}\end{array}$ & $\begin{array}{c}0.060 \\
(2.65)^{* * *}\end{array}$ & $\begin{array}{c}0.106 \\
(5.08)^{* * *}\end{array}$ & & \\
\hline $\begin{array}{l}\text { Portfolio return }(\operatorname{lag} 1)> \\
\text { Market return (lag } 1) \text { (Dummy) }\end{array}$ & $\begin{array}{c}0.012 \\
(2.60)^{* * *}\end{array}$ & $\begin{array}{c}0.012 \\
(2.59)^{* * *}\end{array}$ & & & & \\
\hline $\begin{array}{l}\text { Market return } \\
\text { (past six months) } \\
\text { Portfolio return } \\
\text { (past six months) }\end{array}$ & & & $\begin{array}{c}0.032 \\
(2.57)^{* *} \\
0.012 \\
(1.72)^{*}\end{array}$ & $\begin{array}{c}0.083 \\
(6.76)^{* * *} \\
0.035 \\
(4.88)^{* * *}\end{array}$ & & \\
\hline Market return $(+)(\operatorname{lag} 1)$ & & & & & $\begin{array}{c}0.315 \\
(6.76)^{* * *}\end{array}$ & $\begin{array}{c}0.404 \\
(8.88)^{* * *}\end{array}$ \\
\hline Market return $(-)(\operatorname{lag} 1)$ & & & & & $\begin{array}{c}0.318 \\
(5.36)^{* * *}\end{array}$ & $\begin{array}{c}0.149 \\
(2.54)^{* *}\end{array}$ \\
\hline Portfolio return $(+)(\operatorname{lag} 1)$ & & & & & $\begin{array}{c}0.148 \\
(5.36)^{* * *}\end{array}$ & $\begin{array}{c}0.122 \\
(4.67)^{* * *}\end{array}$ \\
\hline Portfolio return $(-)(\operatorname{lag} 1)$ & & & & & $\begin{array}{l}0.042 \\
(1.12)\end{array}$ & $\begin{array}{c}0.214 \\
(5.74)^{* * *}\end{array}$ \\
\hline Constant & $\begin{array}{c}0.592 \\
(25.65)^{* * *}\end{array}$ & $\begin{array}{c}-0.737 \\
(9.66)^{* * *}\end{array}$ & $\begin{array}{c}0.415 \\
(21.08)^{* * *}\end{array}$ & $\begin{array}{c}0.803 \\
(22.51)^{* * *}\end{array}$ & $\begin{array}{c}0.594 \\
(25.76)^{* * *}\end{array}$ & $\begin{array}{c}-0.786 \\
(10.02)^{* * *}\end{array}$ \\
\hline Observations & 76011 & 76011 & 63925 & 63925 & 76011 & 76011 \\
\hline Groups & 1917 & 1917 & 1853 & 1853 & 1917 & 1917 \\
\hline R-squared overall & 0.19 & 0.02 & 0.22 & 0.11 & 0.19 & 0.02 \\
\hline R-squared within & 0.10 & 0.11 & 0.09 & 0.12 & 0.10 & 0.11 \\
\hline $\mathrm{R}$-squared between & 0.51 & 0.01 & 0.73 & 0.14 & 0.51 & 0.01 \\
\hline
\end{tabular}









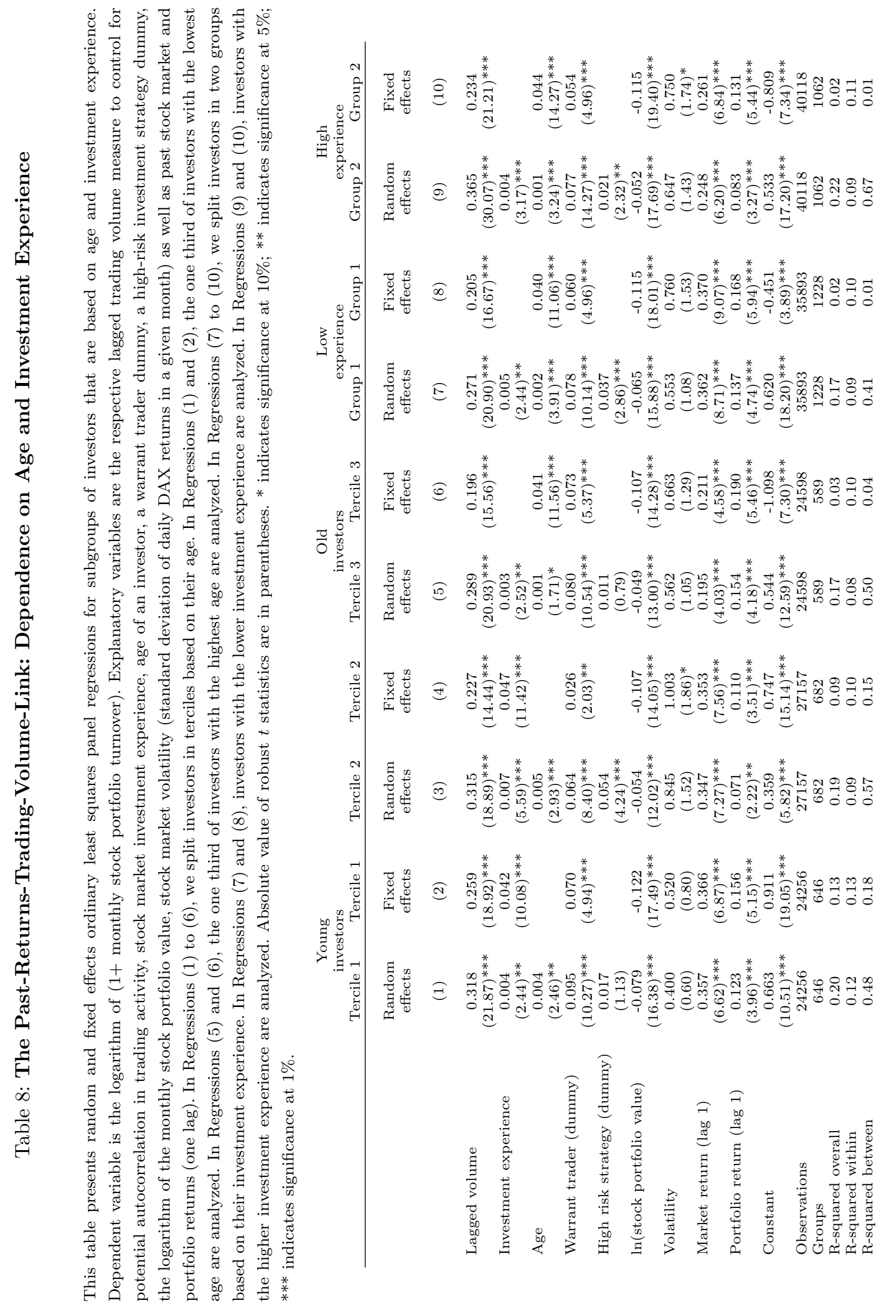




\section{Table 9: Summary of Model Predictions}

This table summarizes the predictions of theories discussed in Section 5. The table lists the respective explanation (first column) and which return variable should drive trading activity in the respective theory (second column). After that, we identify the predictions of the respective theory concerning the risk of stocks purchased and the degree of (under-)diversification afterwards. The last column briefly sketches the nature of the effect or the mechanism of the respective link. Details can be found in Section 5 .

\begin{tabular}{|c|c|c|c|c|}
\hline $\begin{array}{l}\text { Theoretical } \\
\text { explanation }\end{array}$ & Which return? & $\begin{array}{l}\text { Effect on } \\
\text { trading activity }\end{array}$ & $\begin{array}{l}\text { Effect on } \\
\text { risk of stocks purchased }\end{array}$ & Nature of effect \\
\hline $\begin{array}{l}\text { Overconfidence } \\
\text { (miscalibration) }\end{array}$ & Market return & Positive & Positive & $\begin{array}{l}\text { Underestimation of risk: } \\
\text { Prediction intervals too tight }\end{array}$ \\
\hline $\begin{array}{l}\text { Overconfidence } \\
\text { (better than average effect) }\end{array}$ & Portfolio return & Positive & Positive & Biased self-attribution \\
\hline Portfolio rebalancing & Portfolio return & Positive & No effect / unclear & $\begin{array}{l}\text { Need to rebalance due to } \\
\text { changes in asset prices }\end{array}$ \\
\hline Participation & Market return & Positive & No effect / unclear & $\begin{array}{l}\text { Participation costs lower } \\
\text { due to higher market returns }\end{array}$ \\
\hline Disposition effect & Portfolio return & Positive & No effect / unclear & $\begin{array}{l}\text { Selling of winners, holding } \\
\text { of losers e.g. due to loss aversion }\end{array}$ \\
\hline Differences of opinion & Market return & Positive & No effect / unclear & $\begin{array}{l}\text { High returns increase divergence } \\
\text { of opinion of investors }\end{array}$ \\
\hline
\end{tabular}


Table 10: The Effects of Past Returns on Risk of Stock Purchases and the Number of Stocks in the Portfolio

This table presents random and fixed effects ordinary least squares panel regressions of the risk of stock purchases on several explanatory variables (Regressions (1) to (6)). Dependent variable is the logarithm of the average market-to-book ratio of stocks purchased in a given month (Regressions (1) and (2)), the average standard deviation of daily returns of stocks purchased in a given month (Regressions (3) and (4)), and the logarithm of the average market capitalization of stocks purchased in a given month (Regressions (5) and (6)). Before averaging, the market-to-book ratio, the standard deviation of daily returns, and the market capitalization of stocks traded are winsorized at the 1 percent level. Regression (7) contains a pooled negative binomial panel regression. Dependent variable is the number of stocks in investors' portfolios in a given month. Explanatory variables are the respective lagged dependent variables to control for potential autocorrelation, stock market investment experience, age of an investor, a warrant trader dummy, a high-risk investment strategy dummy, the logarithm of the monthly stock portfolio value, stock market volatility (standard deviation of daily DAX returns in a given month) as well as past stock market and portfolio returns (one lag). Absolute value of robust $t$ statistics are in parentheses. * indicates significance at $10 \% ; * *$ indicates significance at $5 \% ; * * *$ indicates significance at $1 \%$.

\begin{tabular}{|c|c|c|c|c|c|c|c|}
\hline & \multicolumn{2}{|c|}{$\begin{array}{l}\ln (\text { average } \\
\text { market-to-book ratio } \\
\text { of purchased stocks) }\end{array}$} & \multicolumn{2}{|c|}{$\begin{array}{c}\text { average standard deviation } \\
\text { of daily returns } \\
\text { of purchased stocks }\end{array}$} & \multicolumn{2}{|c|}{$\begin{array}{c}\ln (\text { average } \\
\text { market capitalization } \\
\text { of purchased stocks) }\end{array}$} & \multirow{2}{*}{$\begin{array}{c}\text { Number of } \\
\text { stocks in portfolio } \\
\begin{array}{c}\text { Pooled } \\
\text { negative binomial } \\
\text { regression }\end{array}\end{array}$} \\
\hline & $\begin{array}{l}\text { Random } \\
\text { effects }\end{array}$ & $\begin{array}{l}\text { Fixed } \\
\text { effects }\end{array}$ & $\begin{array}{l}\text { Random } \\
\text { effects }\end{array}$ & $\begin{array}{l}\text { Fixed } \\
\text { effects }\end{array}$ & $\begin{array}{l}\text { Random } \\
\text { effects }\end{array}$ & $\begin{array}{l}\text { Fixed } \\
\text { effects }\end{array}$ & \\
\hline & (1) & (2) & (3) & (4) & (5) & (6) & (7) \\
\hline $\begin{array}{l}\text { Lagged } \ln \text { (average market-to-book } \\
\text { ratio of purchased stocks) }\end{array}$ & $\begin{array}{l}0.314 \\
(26.11)^{* * *}\end{array}$ & $\begin{array}{c}0.173 \\
(11.78)^{* * *}\end{array}$ & & & & & \\
\hline $\begin{array}{l}\text { Lagged average standard deviation of } \\
\text { daily returns of purchased stocks }\end{array}$ & & & $\begin{array}{c}0.183 \\
(17.36)^{* * *}\end{array}$ & $\begin{array}{c}0.073 \\
(6.29)^{* * *}\end{array}$ & & & \\
\hline $\begin{array}{l}\text { Lagged ln(average market capitalization } \\
\text { of purchased stocks) }\end{array}$ & & & & & $\begin{array}{c}0.285 \\
(34.18)^{* * *}\end{array}$ & $\begin{array}{c}0.119 \\
(12.99)^{* * *}\end{array}$ & \\
\hline $\begin{array}{l}\text { Lagged number of stocks in } \\
\text { portfolio }\end{array}$ & & & & & & & $\begin{array}{c}0.061 \\
(28.13)^{* * *}\end{array}$ \\
\hline Investment experience & $\begin{array}{l}0.002 \\
(0.68)\end{array}$ & $\begin{array}{c}0.046 \\
(3.99)^{* * *}\end{array}$ & $\begin{array}{c}0.001 \\
(9.53)^{* * *}\end{array}$ & $\begin{array}{c}0.008 \\
(26.63) * * *\end{array}$ & $\begin{array}{c}0.016 \\
(2.47)^{* *}\end{array}$ & $\begin{array}{c}0.235 \\
(13.23)^{* * *}\end{array}$ & $\begin{array}{r}-0.001 \\
(0.55)\end{array}$ \\
\hline Age & -0.003 & & -0.000 & & 0.014 & & $\begin{array}{l}-0.003 \\
(506)^{* * *}\end{array}$ \\
\hline Warrant trader (dummy) & 0.054 & 0.109 & 0.008 & 0.003 & -0.160 & -0.032 & 0.023 \\
\hline High risk strategy (dummy) & $\begin{array}{c}(2.38) \\
-0.000 \\
(0.01)\end{array}$ & $(2.43)^{* * *}$ & $\begin{array}{c}(10.08) \\
0.002 \\
(1.15)\end{array}$ & $(2.16)^{* * *}$ & $\begin{array}{c}(3.74) \\
(5.26)^{* * *}\end{array}$ & $(0.43)$ & $\begin{array}{l}(1.86)^{*} \\
-0.007 \\
(0.34)\end{array}$ \\
\hline $\ln ($ stock portfolio value) & 0.028 & 0.011 & 0.002 & 0.000 & 0.129 & 0.079 & 0.195 \\
\hline & $(3.50)^{* * *}$ & $(0.76)$ & $(6.99)^{* * *}$ & $(0.91)$ & $(8.94) * * *$ & $(3.59)^{* * *}$ & $(26.64) * * *$ \\
\hline Volatility & $\begin{array}{r}-0.441 \\
(0.25)\end{array}$ & $\begin{array}{r}-0.946 \\
(0.51)\end{array}$ & $\begin{array}{l}0.850 \\
(17.71)^{* * *}\end{array}$ & $\begin{array}{c}0.922 \\
(18.52)^{* * *}\end{array}$ & $\begin{array}{c}10.839 \\
(3.67)^{* * *}\end{array}$ & $\begin{array}{c}10.691 \\
(3.64)^{* * *}\end{array}$ & $\begin{array}{l}0.898 \\
(3.31)^{* * *}\end{array}$ \\
\hline Market return (lag 1) & -0.237 & -0.174 & 0.005 & $0.009 *$ & 0.274 & 0.343 & -0.033 \\
\hline Portfolio return (lag 1 ) & 0.441 & 0.413 & 0.012 & 0.015 & $\begin{array}{l}(1.14) \\
0.071\end{array}$ & $\begin{array}{l}(1.45) \\
0.110\end{array}$ & -0.129 \\
\hline Constant & $\begin{array}{l}(6.06)^{* * *} \\
0.860\end{array}$ & $\begin{array}{l}(5.09)^{* * *} \\
0.621\end{array}$ & $\begin{array}{l}(4.10)^{* * *} \\
0.007\end{array}$ & $\begin{array}{l}(4.84)^{* * *} \\
-0.054\end{array}$ & $\begin{array}{l}(0.59) \\
4.073\end{array}$ & $\begin{array}{l}(0.90) \\
4.358\end{array}$ & $(8.34)^{* * *}$ \\
\hline Constant & $(9.60)^{* * *}$ & $(4.52)^{* * *}$ & $(2.33)^{* *}$ & $(14.66)^{* * *}$ & $(24.39)^{* * *}$ & $(21.78)^{* * * *}$ & $(6.93)^{* * * *}$ \\
\hline Observations & 8753 & 8753 & 19046 & 19046 & 19014 & 19014 & 76011 \\
\hline Groups/clusters & 1289 & 1289 & 1661 & 1661 & 1657 & 1657 & 1917 \\
\hline R-squared overall & 0.18 & 0.07 & 0.09 & 0.01 & 0.20 & 0.03 & n.a. \\
\hline R-squared within & 0.04 & 0.04 & 0.06 & 0.09 & 0.03 & 0.04 & n.a. \\
\hline R-squared between & 0.39 & 0.13 & 0.21 & 0.01 & 0.47 & 0.05 & n.a. \\
\hline
\end{tabular}


Figure 1: Time series of the DAX from January 1997 to March 2001 (End of Month Values) and of the Number of Stock Transactions

This figure plots the time series of the DAX from January 1997 to March 2001 (end of month values) and the time series of the sum of stock transactions of a sample of about 3,000 individual investors of a German online broker each month (see Section 3 for details about the investor sample). Time period is January 1997 to March 2001.

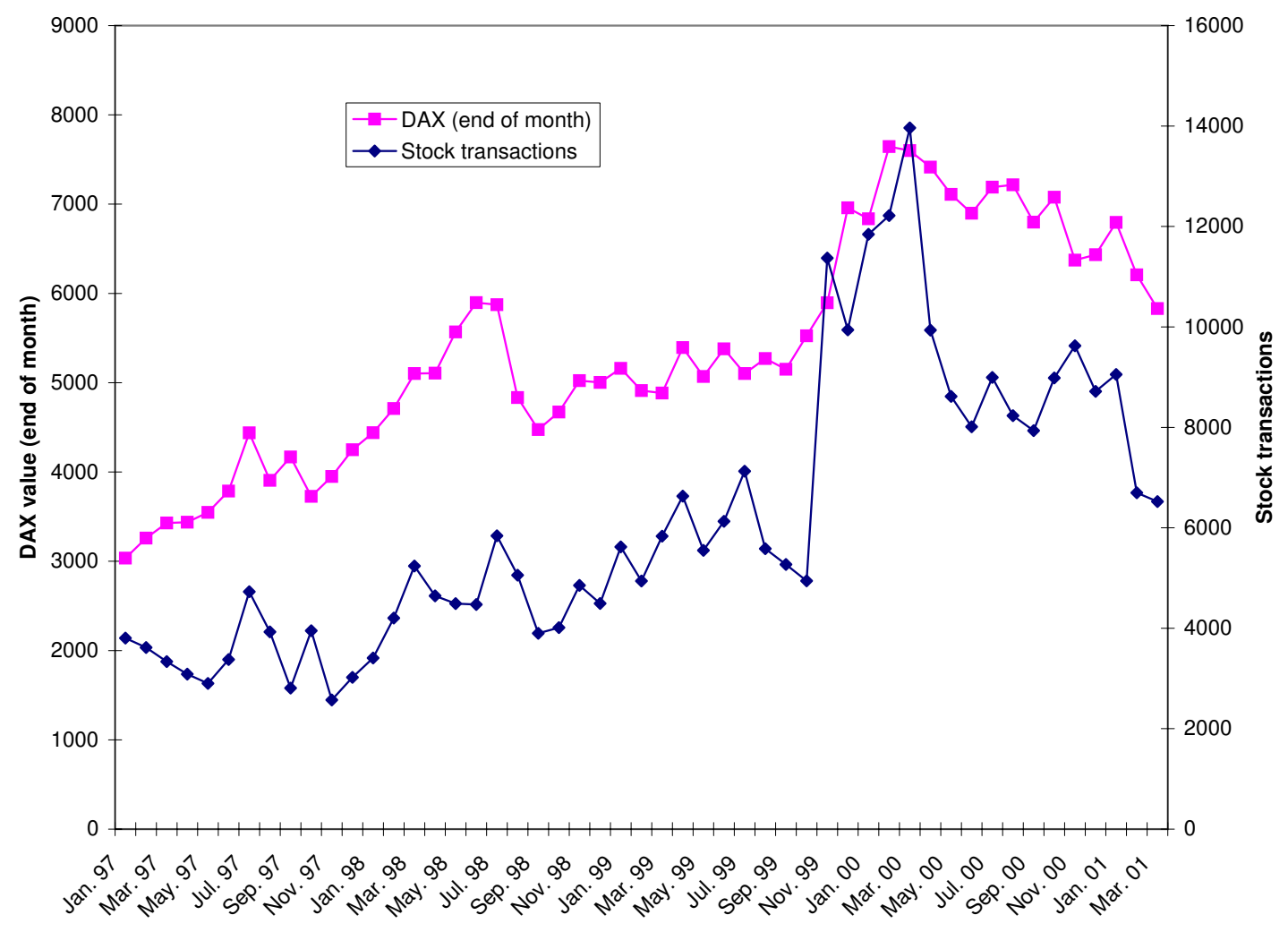

